\title{
The Human Body Known Through the Renovated Museum of Anatomy From the Faculty of Dentistry of Ribeirão Preto
}

\author{
Conocimiento del Cuerpo Humano a través del Renovado Museo \\ de Anatomía de la Facultad de Odontología de Ribeirão Preto
}

\author{
Giovani Antônio Rodrigues*; Pedro Franco Ferreira*;Bianca Carrilho Morando*; \\ João Paulo Mardegan Issa* \& Mamie Mizusaki Iyomasa*
}

\begin{abstract}
RODRIGUES, G. A.; FERREIRA, P. F.; MORANDO, B. C.; ISSA, J. P. M. \& IYOMASA, M. M. The human body known through the renovated museum of anatomy from the faculty of dentistry of Ribeirão Preto. Int. J. Morphol., 33(3):1078-1084, 2015.

SUMMARY: The present work aimed to preserve anatomical specimens to improve the quality of education, prepare supporting materials, and present lectures on the anatomy of the nervous system for public school students. Anatomical specimens related to the nervous system were photographed and named, and acrylic containers filled with formaldehyde were made for the accommodation of these specimens. After research on the subject a handbook and a banner were prepared, enriching the collections of the museum along with the anatomical specimens, in addition to the lecture and video available on "iptv.usp.br ". Meetings between the students, the teachers involved, and the members of the Secretariat of Education of Ribeirao Preto defined schools, dates, times, and duration for the lectures. A great interest and curiosity on the part of the students who attended the lectures has led to the identification of the structures of the body and correlated them with their functions as well as some of the most common illnesses. This project also explained doubts about psychotropic drugs, which in Brazil are highly diffused and awakened reflection on the importance of prevention of diseases and the risk of drugs to their users. It is concluded that the present work has enabled the extension of acquired university knowledge for the community of this city, securing the principles of culture and extension.
\end{abstract}

KEY WORDS: Neuroanatomy; Museum; Learning; Culture and extension.

\section{INTRODUCTION}

The human body is an integrated set of complex and interdependent systems that confers on its holder the ability to adapt and live in various environments of planet Earth. Although it is very much studied, there is still a long way to go until the complete understanding of its functions is known (Lent, 2002; Purves et al., 2001).

Prior to the use of writing, curiosity of the human body and its functioning led people to devote themselves to a detailed study of this vast field of research. Science with its technology has contributed to knowledge of the mechanisms of operation and composition of the human body. The discipline of anatomy has been dedicated to the study of the structures that make up the body.

However in actuality, the acquisition of corpses as study material has become increasingly difficult. Thus, it has become important to enhance and modify the mission of the museum of anatomy, transforming it into an important tool in the learning process for the academic community and society. Also, it is essential to seek methods with the aim to preserve the best anatomical specimens. The proper preparation and identification of these parts displayed in a proper space will extend the knowledge of anatomy and physiology to the population. It will also correlate everyday events such as drugs and pain, in a clear, concise, and objective way.

This Culture and Extension project, carried out with more presentable anatomical specimens than those existing, enriched the collection of the Museum Prof. Edgard Ignácio Museum of Anatomy at the School of Dentistry of Ribeirão Preto (FORP - USP), and searched for an optimistic outlook for the discipline of anatomy at the present time. In this way, even with the lack of anatomical specimens and the difficulties in terms of storage, this project aimed to help the learning process.

\footnotetext{
* Departamento de Morfologia, Fisiologia e Patologia Básica (DMFPB), Faculdade de Odontologia de Ribeirão Preto (FORP), Universidade de São Paulo, Ribeirão Preto, Brasil.
} 
Due to the complexity of all the human body systems it was decided to start the project with the nervous system, an incredible machine, composed of different types of cells that are responsible for the entire human body coordination (Lent; Purves et al.). This magnificent system was correlated with current topics such as Alzheimer's disease, Parkinson's disease, neuromuscular disorders, pain, drugs and strokes, the content of which was extended to elementary and high school students.

This work had as its audience the entire community of Ribeirão Preto, especially $7^{\text {th }}$ grade elementary school students and Education of Young People and Adults (EYPA) public schools in the same city. The objectives were:

- Renovate the Museum Prof. Edgard Ignácio Museum of Anatomy through the construction of acrylic containers to store anatomical specimens, duly prepared by laboratory specialists of the Department of Morphology, Physiology, and Basic Pathology of the School of Dentistry of Ribeirão Preto (FORP USP).

- Stimulate means of conservation and preservation of anatomical specimens for better education.

- Search in detail the nervous system in specific bibliographies.

- Organize lectures and make support materials for students of public schools of the city of Ribeirao Preto/ SP.

- Extend the learning content of the anatomy of the human body through exploration of anatomical specimens, to students of primary and secondary education.

- Awaken interest and reflection on the importance of maintaining human health and prevention of diseases through identification of the body structures and their correlations with the functions, as well as some of the most common illnesses.

\section{MATERIAL AND METHOD}

This Culture and Extension project was divided into two main steps which are described below.

During the second half of 2013, the activities were restricted to the laboratory of anatomy of the School of Dentistry of Ribeirão Preto (FORP - USP). Some anatomical specimens related to the nervous system were separated and photographed, and the more significant structures were identified. Additionally, acrylic preservative containers were made for accommodation of these samples.
At the end of this step, a concise handbook was prepared after searches of renowned bibliographies in the area of Neuroanatomy and specific entities of some pathologies. This handbook will be placed next to the selected anatomical specimens at the museum of anatomy, for visitors to have access to information on the nervous system.

After the completion of these activities, meetings were held between the academics, the teachers involved, and the members of the Secretariat of Education of Ribeirão Preto to define schools, dates, times, and duration of the presentation. The schedule is shown at Table I.

In the first half of 2014, demonstration models and multimedia presentations were made containing pictures and animations about the nervous system, drugs, neurodegenerative diseases, neuromuscular disorders, and stroke, among other diseases. In addition, material containing exercises such as word search, crosswords, and images on the theme of the presentation, and an evaluation questionnaire were designed. The academics and the teacher in charge presented the project to the Secretariat of Education of Ribeirao Preto. The coordinator of the Secretariat was enthusiastic and requested a presentation for teachers of Science and Physical Education at the Casa da Ciência. After this, eight $7^{\text {th }}$ grade classes and five from Education of Young People and Adults (EYPA) were selected to receive the presentation about the nervous system.

The presentations took place in public schools of the city during the class period (morning, afternoon and evening). During the conversation with the students the demonstration models and some newer anatomical specimens were presented, in addition to small animations and videos that helped students to better understand the content. The presentations followed different paths for each class because attention was also given to doubts, knowledge, and everyday situations brought by the students. The major goal was to associate the scientific knowledge with the experiences of each student during the presentations, with the help of the teachers involved. In this way, in addition to the programed content, academics responded to several questions from the students, which included topics such as the mechanism of vision, skin sensitivity, paraplegia, tetraplegia, osteology, mechanisms of sleep and fear, and epilepsy among others.

At the end of each presentation a questionnaire, in which it was not necessary to identify the student, containing questions for evaluation of the presentation theme, quality of the slideshow (images, animations) and performance of academics, was distributed. All these 
RODRIGUES, G. A.; FERREIRA, P. F.; MORANDO, B. C.; ISSA, J. P. M. \& IYOMASA, M. M. The human body known through the renovated museum of anatomy from the faculty of dentistry of Ribeirão Preto. Int. J. Morphol., 33(3):1078-1084, 2015.

Table I. Activities developed at schools.

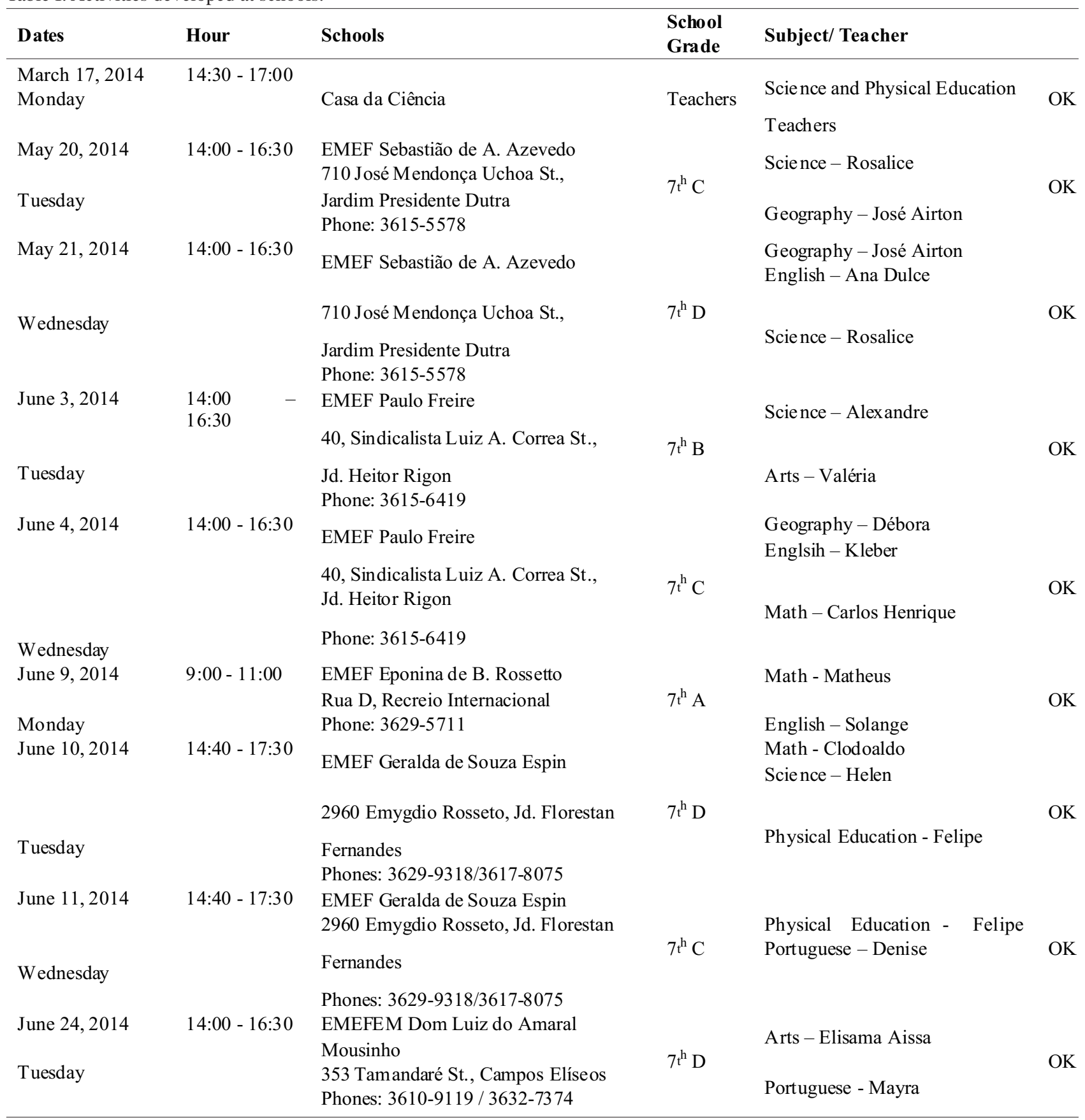

questions should be answered on a scale that ranged from 0 to 10 . There were also two questions related to the importance of learning from anatomical specimens. In addition, a booklet containing word search, crosswords and images about the presented theme were distributed for securing the knowledge on the part of students.

After all of the presentations the students created a video containing an overview of the nervous system, including morphological and physiological aspects, which were posted on the Internet. Thus, teachers and students from elementary school, high school and adult education could access this content and use it in their classes and studies. In addition to the video, a banner containing photographs of anatomical parts used by the project with all their structures identified was designed, printed and stored in the Museum Prof. Edgard Ignácio of Anatomy to serve as a guide for visitors. 


\section{RESULTS}
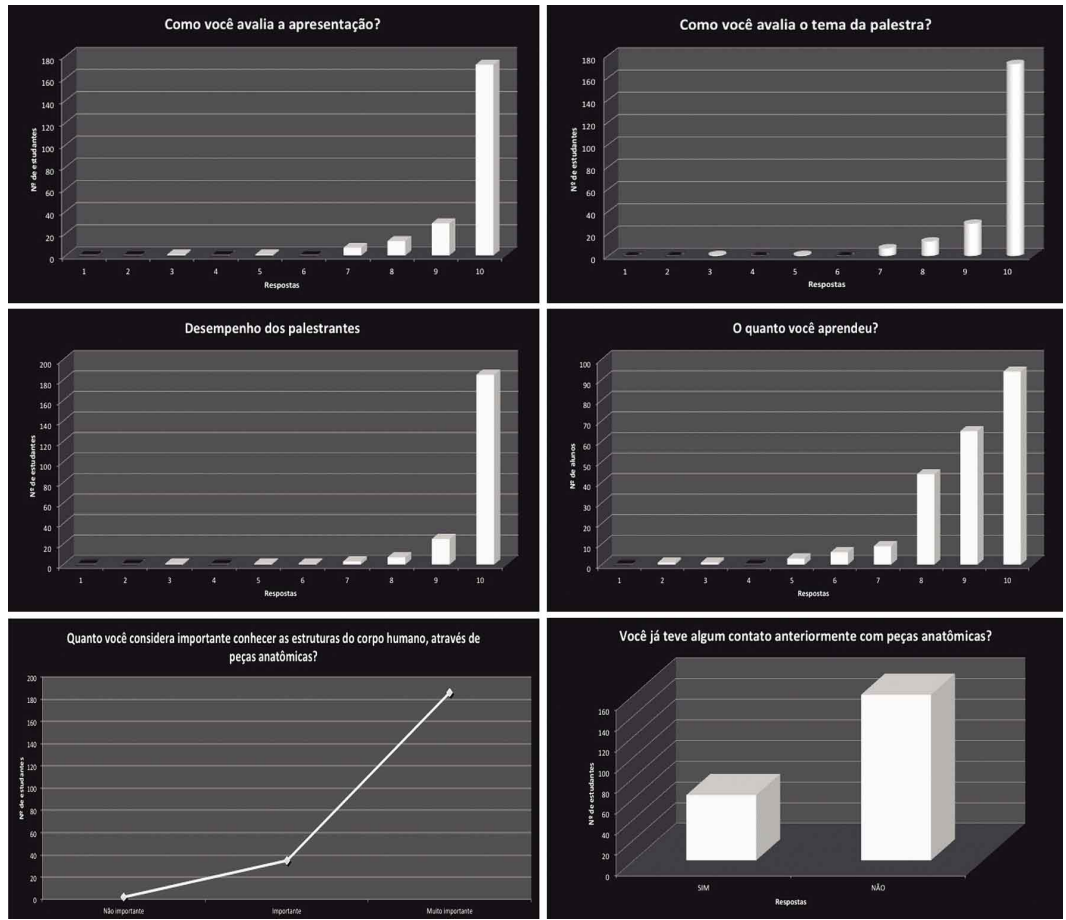

Fig. 1. Answers of the employed questionnaire.
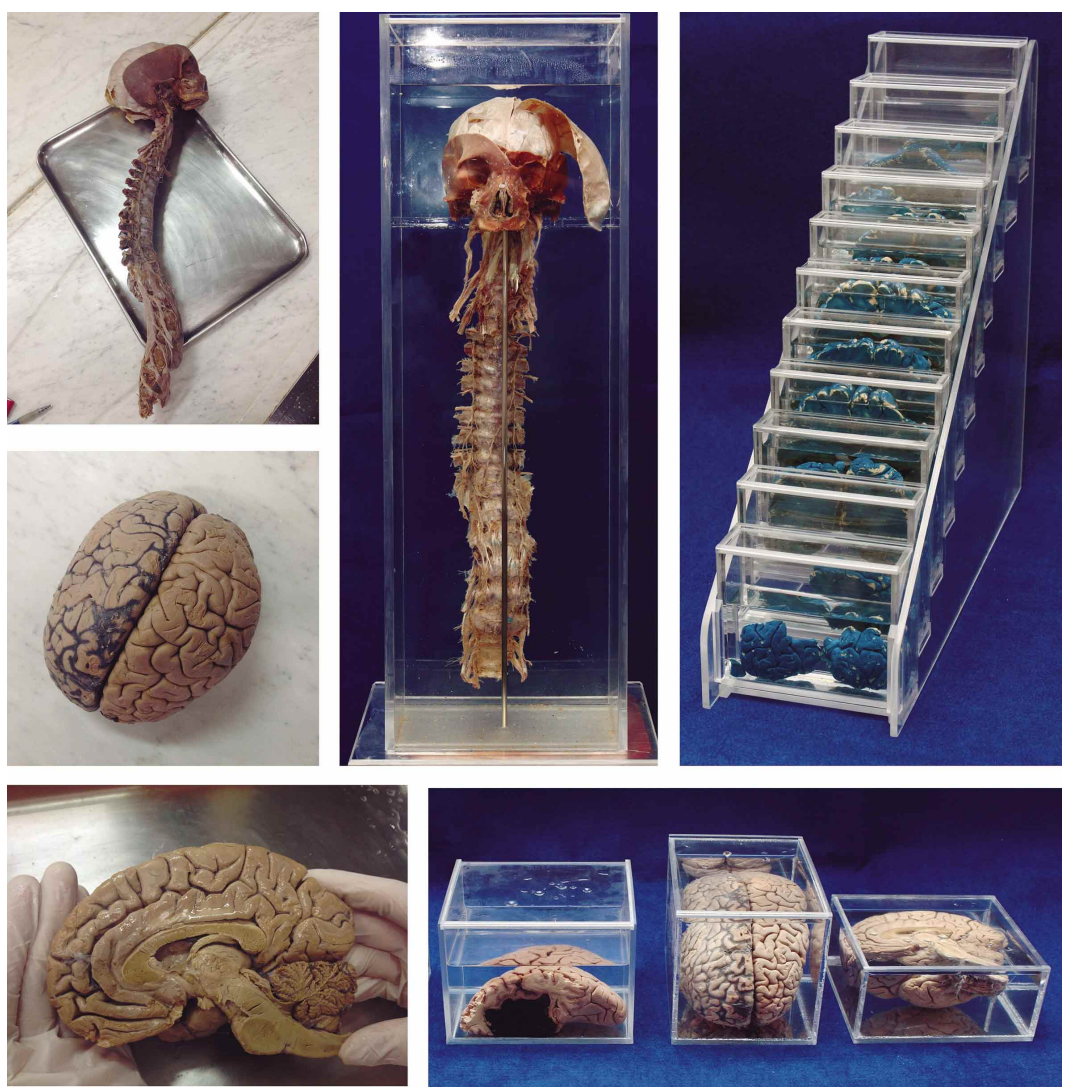

Fig. 2. Past and current conditions of the anatomical pieces.
Twelve presentations were conducted, with an estimated audience of approximately 400 people. Great approval was verified by the students through 223 questionnaires collected, representing only a portion of affected students. The questionnaires were answered according to a scale from 0 to 10 , following growing importance (Fig. 1).

Part of the Museum Dr. Edgard Ignácio of Anatomy was renovated and the anatomical pieces related to the nervous system are now in better storage conditions and therefore better preserved (Figure 2).

The digitalized images of these specimens (Fig. 3) were organized on a didactic banner and important structures were identified using a color key along with a respective caption.

As a result of intense research, a handbook entitled "Exploring the Nervous System" was prepared to accompany the banner and anatomical specimens which were secured in acrylic boxes (Fig. 4).

A video lesson entitled "The Nervous System" was produced as supplementary didactic material, so students of elementary and secondary education and the entire community may visualize the content. It is available on the page "iptv.usp.br " and can be accessed by searching for "Faculty of Dentistry of Ribeirão Preto" (FORP - USP) (Fig. 4).

\section{DISCUSSION}

The complete renovation of the museum of anatomy is extensive, involving multiple systems. The period granted by the Learn with Culture and Extension program allowed the team to highlight a portion of extreme importance, the nervous system, to initiate this project.

This choice was due to the 


\section{CONHECENDO O SISTEMA NERVOSO FACULDADE DE ODONTOLOGIA DE RIBEIRÃO PRETO}

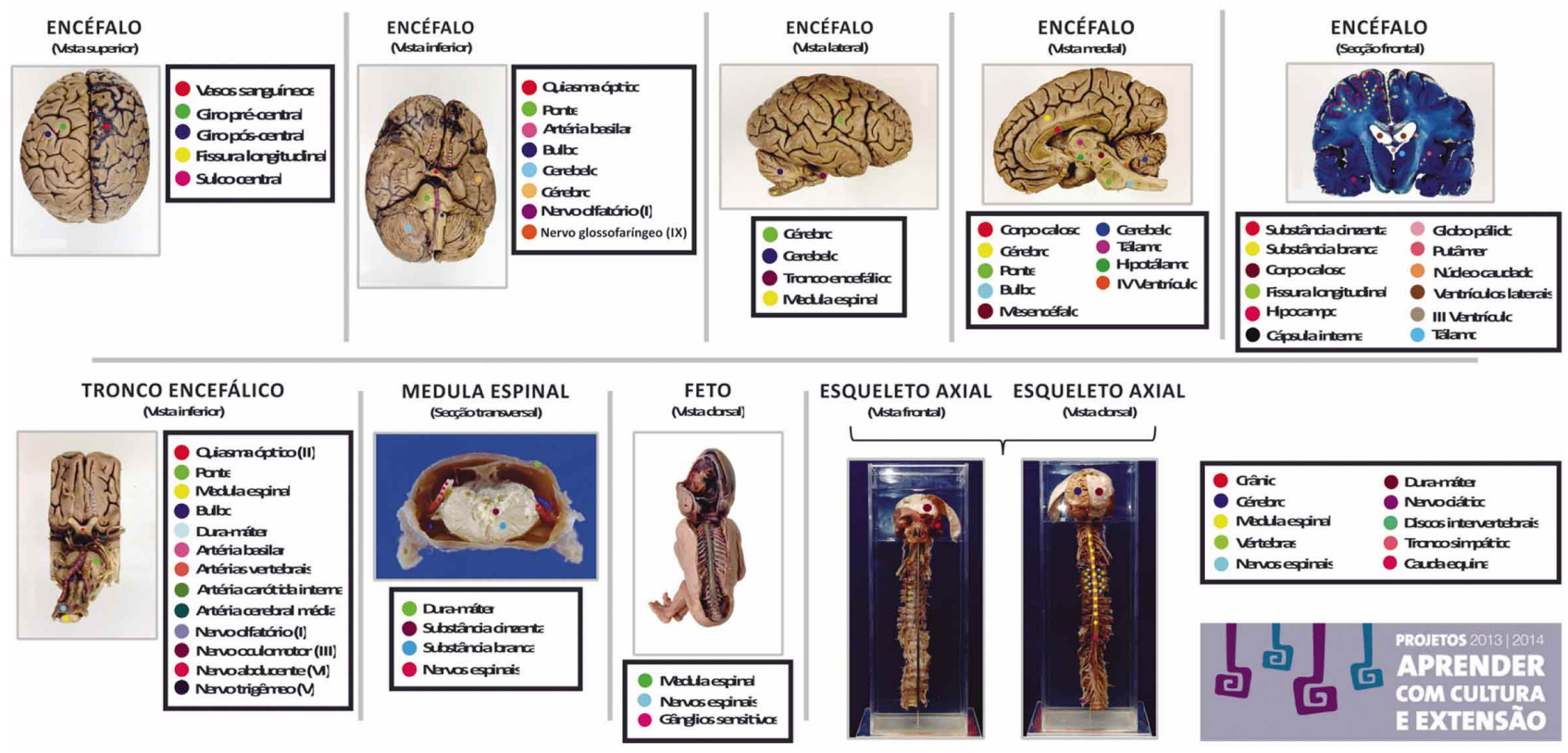

Fig. 3. Digitalized images of these specimens.

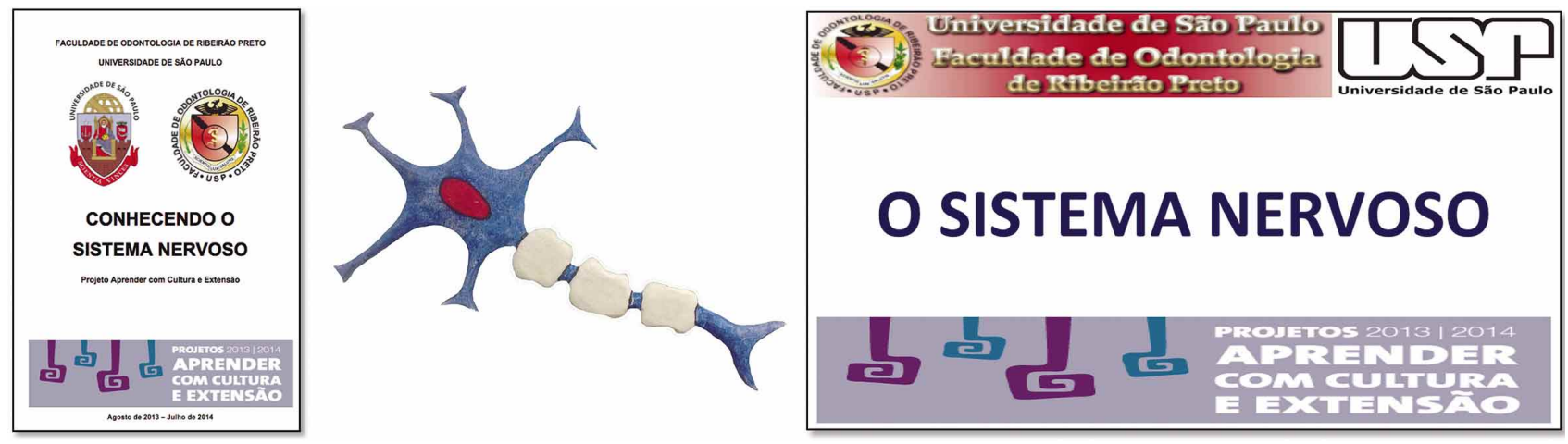

Fig. 4. Handbook, neuron schematic view and video lesson performed by the academics.

possibility of correlating this magnificent system to current topics such as neuromuscular and temporomandibular disorders (da Silva et al., 2006; Barreiros et al., 2014), bone healing process (de Albuquerque et al., 2008), pain and other clinical findings for great interest in people (Siéssere et al., 2009). These pathologies affect a huge portion of the population and therefore were highlighted in the presentations. Here are some data regarding the literature search that deserve attention.
The incidence of Alzheimer's Disease for example, characterized by loss of function caused by the death of brain cells (Steidl et al., 2007), is growing worldwide in the same measure which increases in the population above 65 years of age, affecting 35.6 million people around the world, according to a survey conducted by Alzheimer's Disease International. The forecast is that the number of Alzheimer's patients will reach 65.7 million in 2030 and 115.4 million in 2050. For this reason the World Health Organization included 
Alzheimer's disease as one of the biggest health problems worldwide (Brazilian Association of Alzheimer's Disease, 2013).

Parkinson's Disease in turn, is a chronic and degenerative disease, having its pathogenesis in the central nervous system involving the basal nuclei, being caused by a deficiency of dopamine. It is estimated that this disorder affects approximately $1 \%$ of the world's population over 65 years of age (Meneses \& Teive, 1996). With the aging of the population, both neurodegenerative diseases (Alzheimer's and Parkinson's disease) may have an impact on economic, social and health structures, which will require a greater knowledge about them and an improvement in public health (Silberman et al., 2002).

Regarding stroke, also known as cerebrovascular accident (CVA), it is important to highlight that it shares many of the risk factors of cardiovascular diseases (Almeida, 2012), but with an even higher complexity. Stroke is classified as ischemic, when there is blockage of the blood flow within vessels caused by embolus or blood clot, or as hemorrhagic, due to the leakage of blood into the extracellular space. Studies have evaluated the incidence of CVA in the population, discovering predominance in people above 30 years and with more frequent deaths in women (Pinheiro \& Vianna, 2012).

Another topic discussed during the presentations is regarding the use of alcohol and its effects on the nervous system. Currently Brazil is above the world average in alcohol consumption, and beer represents $60 \%$ of consumption (WHO, 2014). Also, approximately 3.3 million people died worldwide as a result of excessive use of alcoholic beverages (WHO, 2012).

With this project it was possible to clarify students' doubts on these and other themes, such as psychotropic drugs, which in Brazil are highly diffused and cause extreme damage to users.

Furthermore, it was possible to notice a great interest and curiosity on the part of students, pointing out that the students of Education for Young People and Adults (EYPA) showed a greater interaction with the speakers. This occurred, perhaps due to a greater experience of life and curiosity about family situations. The students suggested more presentations with different themes such as sexuality and sexually transmitted diseases (STD's), as well as the continuation of the program.

Finally, this culture and extension project enriched academics, through the knowledge of techniques for storage and operation of the FORP - USP Laboratory of Anatomy, and the knowledge of the necessary technology for the making of the video. In addition, the presentations allowed the team to get to know the reality of public schools of Ribeirao Preto, with their more distinct challenges. It was a rich experience that contributed to the development of human values to the members of the team.

\section{CONCLUSION}

The project from the "Learn with Culture and Extension" program entitled "The human body known through the renovated museum of anatomy from the Faculty of Dentistry of Ribeirao Preto" allowed the team to acquire knowledge through research, and enrich the collection of the museum with more presentable anatomical specimens of the nervous system. This project supported three areas of the university - teaching, research, and extension, and was a valuable and enjoyable experience, with the increase of human values, as the university knowledge was extended to the local community. The making of the video was a tremendous learning experience on the use of technology as didactic material for both the academics and the coordinators. The importance of carrying out similar activities within the university is evident, especially from the Culture and Extension program.

\section{ACKNOWLEDGMENTS}

The academics thank all members and entities listed below for helping with the project:

- Laboratory specialists Luiz Gustavo de Souza and Paulo Batista de Vasconcelos for the dissection of the anatomical specimens;

- Laboratory assistant Túlio Roberto Vasconcelos de Paula Lopes for assistance during the completion of the project;

. Hermano Teixeira Machado for the photographs and video editing.

- Casa da Ciência and the Secretariat of Education of Ribeirão Preto for opening the doors to the development of our project;

- Teachers who accompanied us and scheduled the lectures: Ana Luiza Ricardo Vytal, Clarice Harumi Sakamoto, Lucimar Polo and Antonio Carlos Squilaci Junior;

- To all schools and students who welcomed us. 
RODRIGUES, G. A.; FERREIRA, P. F.; MORANDO, B. C.; ISSA, J. P. M. \& IYOMASA, M. M. Conocimiento del cuerpo humano a través del renovado museo de anatomía de la facultad de odontología de Ribeirão Preto. Int. J. Morphol., 33(3):1078-1084, 2015.

RESUMEN: El presente trabajo tuvo como objetivo preservar especímenes anatómicos para mejorar la calidad de la educación, preparar materiales de apoyo y seminarios sobre la anatomía del sistema nervioso para estudiantes de escuelas públicas. Se fotografiaron y nombraron especímenes anatómicos relacionados con el sistema nervioso, y se prepararon contenedores de acrílico para el alojamiento de estos especímenes sumergidos en un fijador. Después de investigar sobre el tema, se confeccionó un manual y un panel, para enriquecer las colecciones del museo, junto con las piezas anatómicas, además de las conferencias y videos disponibles en la web "iptv.usp.br". Las reuniones entre los estudiantes, profesores y los miembros de la Secretaría de Educación de Ribeirão Preto permitió definir las escuelas participantes, fechas, horas, y duración de las conferencias. Se apreció gran interés y curiosidad por parte de los estudiantes que asistieron a las conferencias, quienes lograron identificar las estructuras del cuerpo y su correlación con algunas de las enfermedades más comunes. Este proyecto también permitió responder las dudas de los estudianteas sobre drogas psicotrópicas, muy difundidas en Brasil y permitió también reflexionar sobre la importancia de la prevención de enfermedades y el riesgo de contraerlas por parte de los usarios de las drogas. Se concluye que el presente trabajo ha permitido ampliar el conocimiento universitario adquirido en la comunidad de esta ciudad, asegurando los principios de cultura y extensión.

PALABRAS CLAVE: Neuroanatomía; Museo; Aprendizaje; Cultura; Extensión.

\section{REFERENCES}

Almeida, S. R. M. Análise epidemiológica do acidente vascular cerebral no Brasil. Rev. Neurocienc., 20(4):481-2, 2012.

Barreiros, V. C.; Dias, F. J.; Iyomasa, M. M.; Coutinho-Netto, J.; de Sousa, L. G.; Fazan, V. P.; Antunes, R. S.; Watanabe, I. S. \& Issa, J. P. Morphological and morphometric analyses of crushed sciatic nerves after application of a purified protein from natural latex and hyaluronic acid hydrogel. Growth Factors, 32(5):164-70, 2014.

Brazilian Association of Alzheimer's Disease. Homepage, 2013. Available from: http://abraz.org.br/

da Silva, M. A.; Issa, J. P.; Vitti, M.; da Silva, A. M.; Semprini, M. \& Regalo, S. C. Electromyographical analysis of the masseter muscle in dentulous and partially toothless patients with temporomandibular joint disorders. Electromyogr. Clin. Neurophysiol., 46(5):263-8, 2006.

de Albuquerque, R. F. Jr.; Aparecida Del Bel, E.; Brentegani, L. G.; Moura de Oliveira, M. T. \& Mardegan Issa, J. P. Trigeminal nitric oxide synthase expression correlates with new bone formation during distraction osteogenesis. Calcif. Tissue Int., 82(4):309-15, 2008.

Lent, R. Cem bilhões de neurônios. Conceitos fundamentais de neurociência. Atheneu/FAPERJ, Rio de Janeiro, 2002.

Meneses, M. S. \& Teive, H. A. G. Doença de Parkinson: Aspectos Clínicos e Cirúrgicos. Rio de Janeiro, Guanabara Koogan, 1996. pp.4-14.

Pinheiro, H. A. \& Vianna, L. G. Taxa de mortalidade específica por doenças cerebrovasculares no Distrito Federal entre 1995 e 2005. Rev. Neurocienc., 20(4):488-93, 2012.
Purves, D.; Agustine, G. J.; Fitzpatrick, D. et al. Neuroscience. 2nd. Ed. Sinauer Assoc., Sunderland, 2001.

Siéssere, S.; Hallak Regalo, S. C.; Semprini, M.; Honorato De Oliveira, R.; Vitti, M.; Mizusaki Iyomasa, M.; Mardegan Issa, J. P. \& De Sousa, L. G. Anatomical variations of the mandibular nerve and its branches correlated to clinical situations. Minerva Stomatol., 58(5):209-15, 2009.

Silberman, C. D.; Marinho, V.; Laks, J. \& Engelhardt, E. Demência e doença de Parkinson. Revisão de publicações brasileiras de 1980 a 2000. Rev. Bras. Neurol., 38:22-30, 2002.

Steidl, E. M.; Ziegler, J. R. \& Ferreira, F. V. Doença de Parkinson: revisão bibliográfica. Disc. Scientia. Cienc. Saúde, 8(1):11529, 2007.

World Health Organization (WHO). Emergencies preparedness, response. Ginebra, World Health Organization (WHO), 2014. Available from: http://www.who.int/csr/don/archive/year/ 2014/en/

World Health Organization (WHO). Emergencies preparedness, response. Ginebra, World Health Organization (WHO), 2012. http://www.who.int/csr/don/archive/year/2012/en/

\section{Correspondence to:}

Profa. Dra. Mamie Mizusaki lyomasa

Departamento de Morfologia

Fisiologia e Patologia Básica (DMFPB)

Faculdade de Odontologia de Ribeirão Preto (FORP)

Universidade de São Paulo (USP)

Avenida do Café, s $/ n^{\circ}$ - Bairro Monte Alegre

14040-904 Ribeirão

Preto-SP - BRASIL

Email: mamieiyo@forp.usp.br 